\title{
Potential benefits of restrictions on the transport of teenage passengers by 16 and 17 year old drivers
}

\author{
L-H Chen, E R Braver, S P Baker, G Li
}

\begin{abstract}
Objectives-The presence of passengers is associated with fatal motor vehicle crashes of teenage drivers. A restriction against newly licensed teenage drivers carrying passengers has been included in some, but not all, graduated licensing systems. The purpose of this study was to predict the net effects on all types of road users, including vehicle occupants and non-occupants, of possible prohibitions against $16-17$ year old drivers carrying passengers.

Methods-Two national datasets, a census of fatal crashes and a sample of trips in the United States, were used to compute 1995 road user death rates. Potential effects of restrictions on drivers ages $16-17$ carrying passengers younger than 20 were estimated, based on road user death rates and potential choices made by passengers who would have traveled with 16-17 year old drivers if there were no restrictions.
\end{abstract}

Results-There were 1181 road user deaths in 1995 involving drivers ages 16-17 whose passengers were all younger than age 20. The predicted number of lives in the United States that would be saved annually ranges from 83 to 493 (corresponding to reductions of $7-42 \%$ in road user deaths) for drivers ages 16 and 17 combined. Similar percentages of reductions $(8-44 \%)$ were predicted solely for 16 year old drivers. Assuming passenger restrictions would apply to all 16 year old drivers and at least one third of 17 year old drivers, an estimated 60-344 fewer deaths per year may occur if restrictions are mandated.

Johns Hopkins School of Public Health, Baltimore, Maryland L-H Chen

S P Baker

Insurance Institute for Highway Safety, Arlington, Virginia E R Braver

Johns Hopkins School of Medicine, Baltimore, Maryland $\mathrm{G} \mathrm{Li}$

Correspondence to:

Li-Hui Chen, Johns Hopkins School of Public Health, 624 North Broadway, Baltimore, MD 21205, USA

lhchen@jhsph.edu ages 16-19 have much higher rates than other drivers regardless of whether the rate is based on miles driven, number of licensed drivers, or unit of population. Sixteen year old drivers have the highest crash rate, followed by 17 and 18-19 year olds. ${ }^{1}$ Teenage drivers and passengers both are affected by this problem. In 1993, 13-19 year old passengers had almost as many deaths as teenage drivers. Two thirds of all teenage passenger deaths involved teenage drivers. ${ }^{2}$ Some studies have reported that the presence of passengers is associated with an increased risk of crash involvement and death among teenage drivers. ${ }^{3-6}$

In response to the high motor vehicle crash risk of 16 and 17 year old drivers, a variety of prevention strategies have been suggested. In recent years, increased attention has been given to graduated licensing systems. The basic premise of these systems is that the beginning driver needs to earn a full privilege license step-by-step and under less dangerous circumstances. Different restrictions are applied in different stages. ${ }^{7}$

Restrictions on carrying passengers are included in some graduated licensing systems. ${ }^{18}$ Based on New Zealand's experience, the prohibition against carrying teenage passengers was the restriction most likely to be ignored by teenagers. ${ }^{9}$ Interviews with parents of 17 year olds, before any American state had a graduated licensing system, indicated this restriction received less support from parents than other restrictions of in these systems. ${ }^{10}$ After graduated licensing laws were adopted in Connecticut and Florida, passenger restrictions received support from about two thirds of parents. ${ }^{11}$

Prohibitions against carrying teenage passengers will change travel exposure patterns but the effect on deaths of all road users has not previously been studied. There are six choices for teenagers who cannot legally ride as passengers if 16 and 17 year old drivers are restricted from transporting them. They may decide not to travel by car, give up the trip, drive themselves, travel with older drivers, be accompanied by older passengers, or ignore the restriction. Although restrictions on carrying passengers are expected to reduce crashes and deaths it is possible that crashes might increase because the restriction could lead to more trips by 16 and 17 year old drivers traveling alone.

Thus it is necessary to estimate the potential effects of passenger restrictions. The first state in the United States to have a law restricting young drivers from carrying passengers younger than age 20 was California, where the restriction went into effect in July 1998. The 1995 data that serve as the basis for our
Keywords: teenage drivers; teenage passengers; motor Keywords: teenage drivers; teenage
vehicle crashes; graduated licensing 


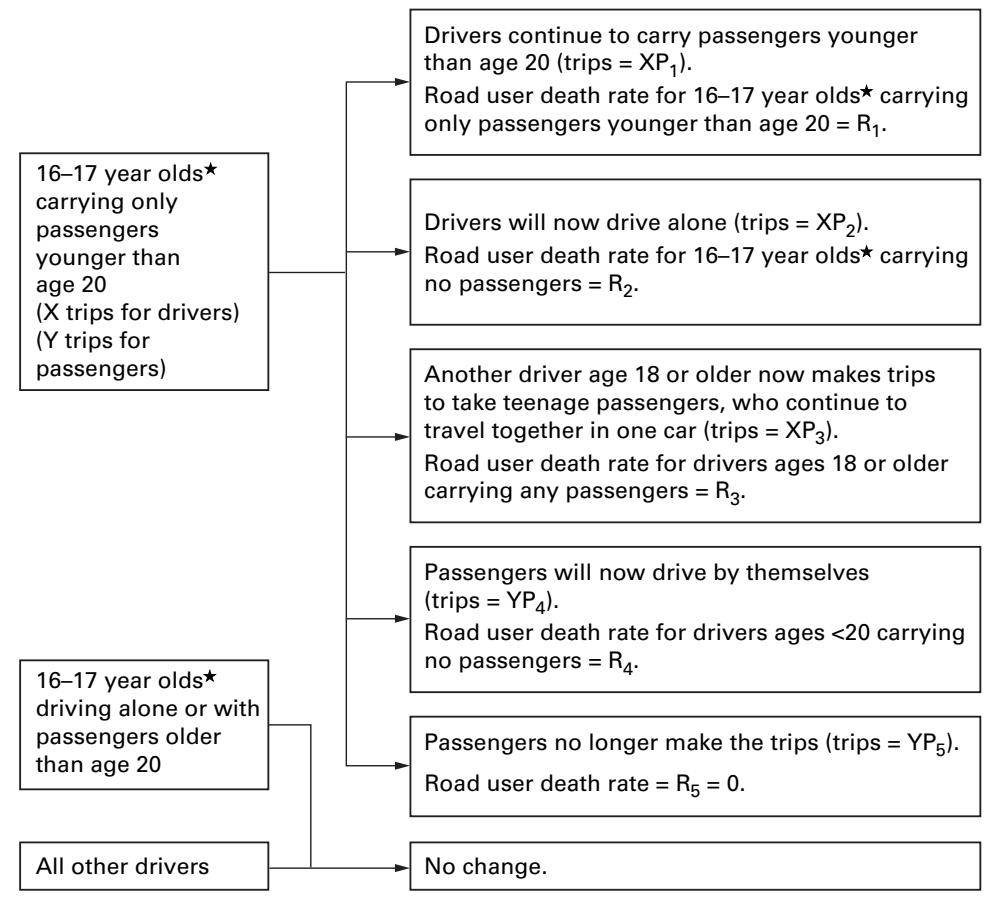

$\star$ Same situations apply to 16 year olds.

Figure 1 Possible responses to restrictions on carrying passengers.

estimates predate the state laws and therefore reflect mortality in the absence of such restrictions.

The objective of this study was to estimate the net effects on traffic deaths in the United States of prohibitions against 16 year old or 16-17 year old drivers carrying passengers younger than age 20, given different percentages of possible choices made by passengers who would have traveled with such drivers if there were no restrictions.

\section{Methods}

Two national datasets, the Fatality Analysis Reporting System (FARS) and the Nationwide Personal Transportation Survey (NPTS), were used. FARS, maintained by the National Highway Traffic Safety Administration, ${ }^{12}$ includes information on all fatal crashes on public roads within the United States in which a death occurred within 30 days of the crash. NPTS data, collected by the Federal Highway Administration, ${ }^{13}$ provide comprehensive information on travel patterns and are obtained from telephone interviews of a stratified sample of United States residents. Because 1995 data are the most recent available for travel patterns, they were used in all analyses.

Assuming a 12 month duration of restrictions on transporting passengers, restrictions would be applicable to virtually all 16 year old drivers and a substantial proportion of 17 year old drivers. Of an estimated 2.4 million licensed 17 year old drivers, about 725000 were first licensed at age $17 .^{14}$ In addition, restrictions would be applicable to those 17 year olds who received their licenses at age 16 but had not yet held them for 12 months. Therefore, the effects of restrictions on carrying passengers younger than age 20 were estimated for drivers ages 16-17 as well as for 16 year old drivers.

All types of road user deaths involving 16 or 17 year old drivers in 1995 were included in the calculations, for example, pedestrians, bicyclists, motorcyclists, and occupants. In addition, any road user deaths involving drivers ages 18 or older transporting passengers were included. Estimated trips of passenger cars, passenger vans, or pickups in 1995 were the measurement of exposure to vehicle travel. Variances for vehicle trips taken by different groups of drivers were calculated using SUDAAN, a software program for analysis of stratified samples. ${ }^{15}$ Trip based road user death rates were calculated for drivers ages 16-17 with and without passengers younger than age 20 and for drivers ages 18 and older with passengers of any age. Ninety five per cent confidence intervals (CI) of the death rates were calculated based on the substitution method described by Daly ${ }^{16}$ using the following formulas:

$\mathrm{F}_{\mathrm{i}}=$ Driver deaths in group $\mathrm{i}$ (from FARS)

$\mathrm{T}_{\mathrm{i}}=$ Trips in group $\mathrm{i}$ (weighted, from NPTS) $\operatorname{Var}\left(T_{i}\right)=$ Variance for $T_{i}$

$\mathrm{F}_{\mathrm{i}} / \mathrm{T}_{\mathrm{i}}=$ Driver death rate in group $\mathrm{i}$

$$
95 \% \text { CI for } F_{i} / T_{i}=\frac{F_{i}}{T_{i} \pm 1.96 \sqrt{\operatorname{Var}\left(T_{i}\right)}}
$$

Potential choices of 16-17 year old drivers whose passengers would all have been younger than age 20 and potential choices of their passengers are illustrated in fig 1 . One alternative for teenagers who could not legally ride as passengers - to be accompanied by passengers ages 20 or older-was omitted in the calculations because data were not available on which to base estimates. Another choice, to use modes of transportation other than passenger vehicles, was also omitted because few trips using other modes were made by people younger than age 20 in 1995. (The effect of these omissions are elaborated upon in the discussion section.) The effects of varying the percentages of drivers and passengers in compliance with restrictions and using different travel options were explored.

To estimate how many teenage passengers were old enough to drive, data from the General Estimates System (GES) were used to obtain the age distributions of passengers in crashes. ${ }^{17}$ GES is a probability sample of all police reported crashes in the United States. Because some geographic areas do not consistently report the presence of uninjured passengers, a protocol was used to exclude these geographic areas. They accounted for about $5 \%$ of crashes involving 16-17 year old drivers during 1992-97 (see Chen et al for details ${ }^{3}$ ). GES data from 1995 showed that only $61 \%$ of the passengers involved in a crash younger than age 20 , carried by 16-17 year old drivers (without accompanying older passengers), were ages 16-19. The remaining passengers were younger than age 16. Therefore, for purposes of estimation, we assumed that the maximum 
proportion of passengers of 16-17 year old drivers who would drive by themselves would be $60 \%$. The same percentage $(60 \%)$ was used for the calculations based solely on 16 year old drivers.

Potential reductions in deaths related to restrictions on drivers ages 16-17 carrying passengers younger than age 20 were estimated using the following formula:

Number of road user deaths before restriction - Estimated number of road user deaths after restriction

Number of road user deaths before restriction

which is equal to:

$\frac{\mathrm{XR}_{1}-\left[\mathrm{XP}_{1} \mathrm{R}_{1}+\mathrm{XP}_{2} \mathrm{R}_{2}+\mathrm{XP}_{3} \mathrm{R}_{3}+\mathrm{YP}_{4} \mathrm{R}_{4}+\mathrm{YP}_{5} \mathrm{R}_{5}\right]}{\mathrm{XR}}$ $\mathrm{XR}_{1}$

$\mathrm{X}=$ Number of trips of $16-17$ year old drivers carrying passengers all younger than age 20, before the restrictions.

$\mathrm{Y}=$ Number of trips of passengers younger than age 20 who were carried by drivers ages $16-17$ without accompanying older passengers, before the restrictions.

$\mathrm{P}_{1}=$ Proportion of $16-17$ year old drivers who will ignore the law.

$\mathrm{P}_{2}=$ Proportion of 16-17 year old drivers who will obey the law.

$\mathrm{P}_{3}=$ Proportion of passengers of 16-17 year old drivers who will get drivers ages 18 or older to drive them (passengers will continue to travel together in one car).

$\mathrm{P}_{4}=$ Proportion of passengers of 16-17 year old drivers who will drive by themselves.

$\mathrm{P}_{5}=$ Proportion of passengers of 16-17 year old drivers who will give up the trips.

$\mathrm{R}_{1}=$ Road user death rates per 10 million trips involving drivers ages 16-17 whose passengers are all younger than age 20 .

$R_{2}=$ Road user death rates per 10 million trips involving drivers ages 16-17 without passengers.

$\mathrm{R}_{3}=$ Road user death rates per 10 million trips involving drivers ages 18 or older carrying passengers.

$\mathrm{R}_{4}=$ Road user death rates per 10 million trips involving drivers younger than age 20 without passengers.

$\mathrm{R}_{5}=$ Road user death rates per 10 million trips involving passengers who will forego the trips (previously transported by 16-17 year old drivers) $=0$.

We assumed $\mathrm{XR}_{1}$ (road user deaths when 16-17 year olds carry passengers younger than age 20) was fixed. The formulas for the $95 \% \mathrm{CI}$ for potential reductions in deaths were as follows:

(1) Variance of reduction in deaths $=$

Variance $\left[\mathrm{XR}_{1}-\left(\mathrm{XP}_{1} \mathrm{R}_{1}+\mathrm{XP}_{2} \mathrm{R}_{2}+\mathrm{XP}_{3} \mathrm{R}_{3}+\right.\right.$ $\left.\left.\mathrm{YP}_{4} \mathrm{R}_{4}+\mathrm{YP}_{5} \mathrm{R}_{5}\right)\right]=$

$\left(\mathrm{P}_{2} \mathrm{R}_{2}\right)^{2}\left[\operatorname{Var}(\mathrm{X})+\left(\mathrm{X} / \mathrm{T}_{2}\right)^{2} \operatorname{Var}\left(\mathrm{T}_{2}\right)\right]$

$+\left(\mathrm{P}_{3} \mathrm{R}_{3}\right)^{2}\left[\operatorname{Var}(\mathrm{X})+\left(\mathrm{X} / \mathrm{T}_{3}\right)^{2} \operatorname{Var}\left(\mathrm{T}_{3}\right)\right]$

$+\left(\mathrm{P}_{4} \mathrm{R}_{4}\right)^{2}\left[\operatorname{Var}(\mathrm{Y})+\left(\mathrm{Y} / \mathrm{T}_{4}\right)^{2} \operatorname{Var}\left(\mathrm{T}_{4}\right)\right]$

$+0$

$\mathrm{T}_{2}=$ Trips involving drivers ages $16-17$ without passengers.
$\mathrm{T}_{3}=$ Trips involving drivers ages 18 or older carrying passengers.

$\mathrm{T}_{4}=$ Trips involving drivers younger than age 20 without passengers.

(2) $95 \%$ CI for reduction in deaths =

Reduction in deaths $\pm 1.96 \sqrt{\text { Variance (reduction in deaths) }}$

SPSS for Windows, SAS, and SUDAAN were used to estimate death rates per unit of travel. ${ }^{151819}$ These software packages also were used to estimate $95 \%$ CI for both the death rates and predicted percentage changes in numbers of deaths.

\section{Results}

There were 1181 road user deaths in 1995 involving drivers ages 16-17 transporting only passengers younger than age 20 (table 1 ). More than half of these deaths (616) involved 16 year old drivers. The road user death rate for drivers ages 16-17 transporting only passengers younger than age $20,7.9$ per 10 million trips, was more than three times the rate for drivers ages 16-17 without passengers and nearly four times the rate for drivers ages 18 or older carrying any passengers. Similar findings were observed for 16 year old drivers.

If 16-17 year old drivers were restricted from carrying passengers younger than age 20 (without any older passengers), $7-42 \%$ fewer road user deaths were predicted (83-493 lives), depending on the distributions of drivers who would violate the law, passengers who would decide to drive by themselves, passengers who would no longer make the trips, and passengers who would go with older drivers (table 2). Similar reductions (8-44\%) in deaths (48-269 lives saved) were predicted solely for 16 year old drivers (table 3). Increased compliance with passenger restrictions increased the estimates of lives saved. Descriptions of different compliance scenarios and their outcomes for 16-17 year old drivers follow.

LOW COMPLIANCE SCENARIO

If compliance rates were as low as $20 \%$ among 16-17 year old drivers and their passengers, with the remaining passengers split equally among those who would drive alone and those who would travel with older drivers, a $7 \%$ reduction in road user deaths is predicted (table 2).

INTERMEDIATE COMPLIANCE SCENARIOS

With compliance rates of $50 \%$ for $16-17$ year old drivers and their passengers, the estimated

Table 1 Death rates ${ }^{*}$, numbers of trips, and numbers of deaths used in calculations, $1995+$

\begin{tabular}{|c|c|c|c|c|c|c|c|c|}
\hline \multirow{2}{*}{$\begin{array}{l}\text { Driver age } \\
\text { (years) }\end{array}$} & \multirow{2}{*}{$\begin{array}{l}\text { Passenger age } \\
\text { (years) }\end{array}$} & \multicolumn{2}{|c|}{ Driver trips (millions) } & \multicolumn{2}{|c|}{ Passenger trips (millions) } & \multicolumn{3}{|c|}{ Road users } \\
\hline & & No & $95 \% C I$ & No & $95 \% C I$ & Deaths & Death rate & $95 \% C I$ \\
\hline 16 & $<20$ only & 639 & 488 to 790 & 926 & 680 to 1172 & 616 & 9.6 & 7.8 to 12.6 \\
\hline 16 & None & 1066 & 884 to 1248 & & & & 3.2 & 2.7 to 3.9 \\
\hline $16-17$ & $<20$ only & 1488 & 1269 to 1708 & 2139 & 1769 to 2509 & 1181 & 7.9 & 6.9 to 9.3 \\
\hline $16-17$ & None & 2903 & 2599 to 3207 & & & & 2.5 & 2.3 to 2.8 \\
\hline $18+$ & Any & 70557 & 69044 to 72072 & & & & 2.1 & 2.1 to 2.1 \\
\hline $16-19$ & None & 7942 & 7325 to 8559 & & & & 2.2 & 2.1 to 2.4 \\
\hline
\end{tabular}

*Deaths per 10 million driver trips.

†Fatality Analysis Reporting System and Nationwide Personal Transportation Survey (travel without restrictions on carrying passengers). 
Table 2 Effects of passenger restrictions on drivers ages 16-17: estimated road user lives saved and per cent reductions in annual road user deaths, given different percentages of potential choices by passengers

\begin{tabular}{|c|c|c|c|c|c|c|c|c|c|}
\hline \multirow[b]{2}{*}{$\begin{array}{l}\text { Compliance } \\
\text { scenarios }\end{array}$} & \multirow[b]{2}{*}{ Passenger behaviors } & \multicolumn{4}{|c|}{ Percentage selecting potential choices } & \multirow[b]{2}{*}{ Lives saved } & \multirow[b]{2}{*}{$95 \% C I$} & \multirow[b]{2}{*}{$\begin{array}{l}\% \text { Deaths } \\
\text { reduced }\end{array}$} & \multirow[b]{2}{*}{$95 \% C I$} \\
\hline & & Disobey law & $\begin{array}{l}\text { Passengers travel } \\
\text { with older drivers }\end{array}$ & $\begin{array}{l}\text { Passengers drive } \\
\text { themselves }\end{array}$ & $\begin{array}{l}\text { Passengers } \\
\text { forego trips }\end{array}$ & & & & \\
\hline Low & Few obey law & 80 & 10 & 10 & 0 & 83 & 68 to 98 & 7 & 6 to 8 \\
\hline Intermediate & $\begin{array}{l}\text { More drive alone } \\
\text { More go with older drivers } \\
\text { Some forego trips }\end{array}$ & $\begin{array}{l}50 \\
50 \\
50\end{array}$ & $\begin{array}{l}10 \\
30 \\
30\end{array}$ & $\begin{array}{l}40 \\
20 \\
10\end{array}$ & $\begin{array}{l}0 \\
0 \\
10\end{array}$ & $\begin{array}{l}183 \\
216 \\
263\end{array}$ & $\begin{array}{l}142 \text { to } 223 \\
178 \text { to } 254 \\
226 \text { to } 300\end{array}$ & $\begin{array}{l}15 \\
18 \\
22\end{array}$ & $\begin{array}{l}12 \text { to } 19 \\
15 \text { to } 21 \\
19 \text { to } 25\end{array}$ \\
\hline \multirow[t]{3}{*}{ High } & $\begin{array}{l}\text { More drive alone } \\
\text { More go with older drivers } \\
\text { Some forego trips }\end{array}$ & $\begin{array}{l}30 \\
30 \\
30\end{array}$ & $\begin{array}{l}20 \\
40 \\
40\end{array}$ & $\begin{array}{l}50 \\
30 \\
20\end{array}$ & $\begin{array}{l}0 \\
0 \\
10\end{array}$ & $\begin{array}{l}266 \\
299 \\
346\end{array}$ & $\begin{array}{l}210 \text { to } 321 \\
245 \text { to } 352 \\
294 \text { to } 398\end{array}$ & $\begin{array}{l}23 \\
25 \\
29\end{array}$ & $\begin{array}{l}18 \text { to } 27 \\
21 \text { to } 30 \\
25 \text { to } 34\end{array}$ \\
\hline & $\begin{array}{l}\text { More drive alone } \\
\text { More go with older drivers } \\
\text { Some forego trips } \\
\text { More forego trips }\end{array}$ & $\begin{array}{l}10 \\
10 \\
10 \\
10\end{array}$ & $\begin{array}{l}40 \\
60 \\
60 \\
60\end{array}$ & $\begin{array}{l}50 \\
30 \\
20 \\
10\end{array}$ & $\begin{array}{l}0 \\
0 \\
10 \\
20\end{array}$ & $\begin{array}{l}365 \\
398 \\
446 \\
493\end{array}$ & $\begin{array}{l}296 \text { to } 434 \\
329 \text { to } 467 \\
378 \text { to } 513 \\
426 \text { to } 560\end{array}$ & $\begin{array}{l}31 \\
34 \\
38 \\
42\end{array}$ & $\begin{array}{l}25 \text { to } 37 \\
28 \text { to } 40 \\
32 \text { to } 43 \\
36 \text { to } 47\end{array}$ \\
\hline & All ages $16-19$ drive alone & 0 & 40 & 60 & 0 & 398 & 321 to 476 & 34 & 27 to 40 \\
\hline
\end{tabular}

Table 3 Effects of passenger restrictions on 16 year old drivers: estimated road user lives saved and per cent reductions in annual road user deaths, given different percentages of potential choices by passengers

\begin{tabular}{|c|c|c|c|c|c|c|c|c|c|}
\hline \multirow[b]{2}{*}{$\begin{array}{l}\text { Compliance } \\
\text { scenarios }\end{array}$} & \multirow[b]{2}{*}{ Passenger behaviors } & \multicolumn{4}{|c|}{ Percentage selecting potential choices } & \multirow[b]{2}{*}{ Lives saved } & \multirow[b]{2}{*}{$95 \% C I$} & \multirow[b]{2}{*}{$\begin{array}{l}\% \text { Deaths } \\
\text { reduced }\end{array}$} & \multirow[b]{2}{*}{$95 \% C I$} \\
\hline & & Disobey law & $\begin{array}{l}\text { Passengers travel } \\
\text { with older drivers }\end{array}$ & $\begin{array}{l}\text { Passengers drive } \\
\text { themselves }\end{array}$ & $\begin{array}{l}\text { Passengers } \\
\text { forego trips }\end{array}$ & & & & \\
\hline Low & Few obey law & 80 & 10 & 10 & 0 & 48 & 35 to 61 & 8 & 6 to 10 \\
\hline Intermediate & $\begin{array}{l}\text { More drive alone } \\
\text { More go with older drivers } \\
\text { Some forego trips }\end{array}$ & $\begin{array}{l}50 \\
50 \\
50\end{array}$ & $\begin{array}{l}10 \\
30 \\
30\end{array}$ & $\begin{array}{l}40 \\
20 \\
10\end{array}$ & $\begin{array}{l}0 \\
0 \\
10\end{array}$ & $\begin{array}{l}110 \\
124 \\
145\end{array}$ & $\begin{array}{l}77 \text { to } 143 \\
92 \text { to } 156 \\
114 \text { to } 177\end{array}$ & $\begin{array}{l}18 \\
20 \\
24\end{array}$ & $\begin{array}{l}12 \text { to } 23 \\
15 \text { to } 25 \\
18 \text { to } 29\end{array}$ \\
\hline High & $\begin{array}{l}\text { More drive alone } \\
\text { More go with older drivers } \\
\text { Some forego trips }\end{array}$ & $\begin{array}{l}30 \\
30 \\
30\end{array}$ & $\begin{array}{l}20 \\
40 \\
40\end{array}$ & $\begin{array}{l}50 \\
30 \\
20\end{array}$ & $\begin{array}{l}0 \\
0 \\
10\end{array}$ & $\begin{array}{l}158 \\
173 \\
193\end{array}$ & $\begin{array}{l}113 \text { to } 204 \\
128 \text { to } 218 \\
149 \text { to } 238\end{array}$ & $\begin{array}{l}26 \\
28 \\
31\end{array}$ & $\begin{array}{l}18 \text { to } 33 \\
21 \text { to } 35 \\
24 \text { to } 39\end{array}$ \\
\hline & $\begin{array}{l}\text { More drive alone } \\
\text { More go with older drivers } \\
\text { Some forego trips } \\
\text { More forego trips }\end{array}$ & $\begin{array}{l}10 \\
10 \\
10 \\
10\end{array}$ & $\begin{array}{l}40 \\
60 \\
60 \\
60\end{array}$ & $\begin{array}{l}50 \\
30 \\
20 \\
10\end{array}$ & $\begin{array}{l}0 \\
0 \\
10 \\
20\end{array}$ & $\begin{array}{l}214 \\
228 \\
249 \\
269\end{array}$ & $\begin{array}{l}156 \text { to } 272 \\
170 \text { to } 286 \\
191 \text { to } 306 \\
212 \text { to } 327\end{array}$ & $\begin{array}{l}35 \\
37 \\
40 \\
44\end{array}$ & $\begin{array}{l}25 \text { to } 44 \\
28 \text { to } 46 \\
31 \text { to } 50 \\
34 \text { to } 53\end{array}$ \\
\hline & All ages $16-19$ drive alone & 0 & 40 & 60 & 0 & 234 & 170 to 299 & 38 & 28 to 49 \\
\hline
\end{tabular}

reductions in road user deaths would range from 15 to $22 \%$ (183-263 lives saved), depending on passengers' actions (table 2). If most of the passengers in compliance with a passenger restriction law would choose to drive alone, then a $15 \%$ reduction (95\% CI 12 to $19 \%$ ) would be expected. Greater percentage reductions in road user deaths are predicted if more passengers would travel with older drivers or forego trips.

HIGH COMPLIANCE SCENARIOS

If $70 \%$ of $16-17$ year old drivers were to comply with the law, road user deaths would be reduced by an estimated 23-29\% (266-346 lives saved) (table 2). Higher compliance rates of $90 \%$ among drivers ages 16-17 are estimated as resulting in $31-42 \%$ reductions in road user deaths.

EFFECT OF PASSENGERS DRIVING ALONE

Road user deaths would be reduced to a still greater extent if increased numbers of older drivers would transport teenage passengers; however, increased numbers of teenage passengers driving alone is not predicted to counterbalance the beneficial effects of passenger restrictions. If all 16-17 year old drivers were to obey a passenger restriction law, and if all teenage passengers of legal driving age $(60 \%$, based on the age distributions of teenage passengers involved in crashes) were to drive alone, then road user deaths are expected to decrease $34 \%$, with 398 lives saved ( $95 \%$ CI 321 to 476 lives saved) (table 2). Even if all teenage passengers of 16-17 year old drivers were to drive alone, including those too young to be driving legally, then a $28 \%$ reduction in road user deaths is estimated.

\section{EFFECT OF PASSENGERS FOREGOING VEHICLE} TRIPS

If $10 \%$ or more of passengers who formerly would have traveled with a 16-17 year old driver were to give up their trips, then substantially more lives would be saved (tables 2 and 3).

\section{Discussion}

Our analysis suggests that restrictions on 16-17 year old drivers carrying passengers younger than age 20 , in the absence of older passengers, are likely to reduce road user deaths substantially. Although the effect of the passenger restrictions is strongly associated with the extent to which the law would be observed, reductions in road user deaths would be expected even with low compliance. If less than half the 16-17 year old drivers obeyed the law, a substantial number of deaths might be prevented. Because road user death rates for 16 and 17 year old drivers with passengers younger than age 20 are more than three times as high as those of young drivers without passengers, the law could be beneficial even if all passengers were to drive by themselves. 
It might be argued that nighttime driving restrictions alone would reduce some of the excess mortality associated with 16 and 17 year old drivers transporting passengers. ${ }^{3}$ However, previous research has observed increased crash risks among teenage drivers carrying passengers in the daytime. ${ }^{3}$ Therefore, nighttime driving restrictions for young drivers cannot substitute for passenger restriction laws.

When estimating the effects of passenger restrictions for 12 months after licensure, calculations based only on 16 year old drivers yielded percentages of reductions in road user deaths similar to those for 16 and 17 year old drivers combined. The number of lives expected to be saved annually by passenger restrictions falls somewhere between those estimated for 16 year old drivers and those estimated for all drivers ages 16-17. About one third of the licensed 17 year old drivers are first licensed at age $17 .{ }^{14}$ It is reasonable to assume that passenger restrictions would apply to all 16 year old drivers and at least one third of 17 year old drivers; therefore, an estimated 60-344 fewer deaths per year may occur if passenger restrictions are included in graduated licensing systems.

Some of the American states that include passenger restrictions in their graduated driver licensing laws have relatively lenient restrictions. Their restrictions are of short duration (90 days) or permit up to three passengers younger than age $21 .^{8}$ Such restrictions would be expected to be less effective than stricter laws. Previous research observed increased risk with only one passenger and a trend toward increasing fatality risk with increasing numbers of passengers. ${ }^{3}$

No prior published research has estimated the potential impact of a restriction on 16 and 17 year old drivers carrying passengers younger than age 20. Langley et al, using time series analysis to estimate the effect of New Zealand's graduated licensing system in which restricting passengers is one component, reported an estimated $7-23 \%$ reduction in car crash injuries for 15-19 year olds. ${ }^{20}$ These percentages are lower than those estimated in the current study for the passenger restriction component alone. However, Langley et al studied only car crash injuries among 15-19 year olds, whereas the current study was based on all road user deaths related to $16-17$ year old drivers. ${ }^{20}$

Compliance with passenger restriction laws will determine their efficacy, and parental oversight will be the most important factor in compliance. One survey in New Zealand found that $92 \%$ of teenagers had at some time disobeyed the passenger restriction; however, the survey did not ask how often the teenagers had done so. ${ }^{9}$ Another survey conducted in Canada reported that $20 \%$ of learners and $39 \%$ of newly licensed drivers admitted they had violated the passenger restriction, but most of the teenagers who had broken the law said they had done so rarely. ${ }^{21}$ A higher percentage of non-compliance was reported when the teenagers were asked how commonly they thought their peers violated the law; they estimated that

\section{Key points}

- Restrictions on carrying teenage passengers should be considered for inclusion in graduated licensing systems.

- The death rate for 16-17 year old drivers carrying passengers younger than 20 is more than three times their death rate without passengers.

- With compliance rates of just $50 \%$ for 16-17 year old drivers and their teenage passengers, passenger carrying restrictions would cause an estimated reduction in road user deaths of $15-22 \%$.

- Restrictions in some states in the United States that are of short duration (90 days) or permit up to three teenage passengers would likely be less effective than stricter laws.

$34 \%$ of learners and $49 \%$ of newly licensed drivers had violated the passenger restriction.

There are no data available documenting how well teenagers in the United States will obey a restriction against carrying passengers, but compliance with nighttime driving restrictions may offer some clues. One review of research in this area found that a majority of surveyed teenagers had violated the driving restrictions, but most of them said they did not do so often. ${ }^{22}$ These studies, together with the experience of other countries, suggest that if restrictions against carrying passengers were applied to teens in the United States, the majority would obey the law most of the time.

Limitations of our study are related to some of the assumptions made in the calculations. We assumed that if a 16 or 17 year old driver surveyed by NPTS carried non-household passengers, then those passengers were younger than age 20 . This assumption, which was necessary because NPTS data do not include the ages of passengers if they are not from the same household as the driver, overestimates the number of passengers younger than age 20 who travel with teen drivers. However, the magnitude of the overestimate probably is slight because young drivers often travel with their friends. ${ }^{23}$ Consequently, death rates of teen passengers with teen drivers are slightly underestimated, which has a corresponding effect on the estimate of the benefits of the restriction on carrying teen passengers.

We also assumed that crash patterns for each occupant combination would not change significantly after the restrictions. If teen drivers' road user death rates with and without teenage or other passengers do change significantly, this could lessen the efficacy of passenger restrictions. For example, the noncompliant drivers who continue to travel with passengers may have higher crash rates than drivers who transported passengers before restrictions. Also, passengers driving themselves after the restrictions may not have the same road user death rates as teenagers who previously drove without passengers in the absence of restrictions. 
Because 16-17 year old drivers account for only a small percentage $(4.5 \%)$ of vehicle travel, road user death rates for drivers age 18 or older likely will change little. Another assumption was that if passengers of a given teenage driver are driven by an older driver (age 18 or older), they will all still travel together in one car. If this assumption is not valid, we have overestimated the beneficial effect of restrictions.

One alternative, that of adding an older passenger to a trip in which passengers otherwise would all be younger than age 20 , was ignored in the calculations because NPTS did not identify such trips. However, based on the analysis of Chen et al carrying passengers ages 20-29 may be even riskier than carrying only teenage passengers. For that reason, a restriction against 16-17 year old drivers carrying passengers younger than age 30 , in the absence of an older supervising driver, might be preferable.

Another alternative, changing to another transportation mode, was ignored in the calculations, because few car trips are expected to change to walking or bicycling trips, particularly in non-urban areas. ${ }^{13}$ Other transportation modes accounted for a small number of trips among people younger than age 20 .

\section{Implications for prevention}

Our results suggest that graduated licensing systems for young drivers that include restrictions on carrying passengers younger than age 20 would save lives. However, evaluation of the restrictions based on real world experience, such as comparison of mortality before and after restriction, will be needed to confirm the efficacy of the laws. Nevertheless, this restriction should be seriously considered by road safety officials.

This work was supported by the Insurance Institute for Highway Safety. The opinions, findings, and conclusions expressed in this publication are those of the author(s) and do not necessarily reflect the views of the Insurance Institute for Highway Safety.
1 Williams AF. Graduated licensing comes to the United States. Inj Prev 1999;5:133-5.

2 Williams AF, Wells JK. Deaths of teenagers as motor vehicle passengers. I Safety Res 1995;26:161-7.

3 Chen LH, Baker SP, Braver ER, et al. Carrying passengers as a risk factor for crashes fatal to 16- and 17-year-old drivers. $7 A M A$ 2000;283:1578-82.

4 Doherty ST, Andrey JC, MacGregor C. The situational risks of young drivers: the influence of passengers, time of day, and day of week on accident rates. Accid Anal Prev 1998;30:45-52.

5 Foldvary LA, Lane JC. Car crash injuries by seating position and miles traveled. Proceedings of 13th Annual Conference of the American Association for Automotive Medicine. Des Plaines, IL: American Association for Automotive Medicine, 1969: 17-72.

6 Preusser DF, Ferguson SA, Williams AF. The effect of teenage passengers on the fatal crash risk of teenage drivers. Accid Anal Prev 1998;30:217-22.

7 Williams AF. Society confronts the young driver problem. Alliams AF. Society confronts the young driver problem.
Arlington, VA: Insurance Institute for Highway Safety, Arling

8 Insurance Institute for Highway Safety. US licensing systems for young drivers. Arlington, VA, 2000. http:// www.highwaysafety.org/safety_facts/state_laws/ licensing_systems.pdf (last accessed 9August 2000).

9 Begg DJ, Langley JD, Reeder AI, et al. The New Zealand graduated driver licensing system: teenagers' attitudes towards and experiences with this car driver licensing system. Inj Prev 1995;1:177-81.

10 Ferguson SA, Williams AF. Parents' views of driver licensing practices in the United States. I Safety Res 1996;27:73-81.

11 Ferguson SA, Williams AF, Leaf WA, et al. Views of parents of teenagers about graduated licensing after experience with the laws. Arlington, VA: Insurance Institute for Highway laws. Arlington,

12 National Highway Traffic Safety Administration. Fatal Accident Reporting System: 1995 annual reports. Washington, DC: dent Reporting System: 1995 annual reports.
US Department of Transportation, 1995.

13 Federal Highway Administration. 1995 Nationwide personal transportation survey. Washington, DC: US Department of Transportation, 1995.

14 Federal Highway Administration. Highway statistics 1997. Report FHWA PL-98-020. Washington, DC: US Department of Transportation, 1998.

15 Research Triangle Institute. SUDAAN, rel. 7.5. Research Triangle Park, NC: Research Triangle Institute, 1998.

16 Daly LE. Confidence limits made easy: interval estimation using a substitution. Am. F Epidemiol 1998;147:783-90.

17 National Highway Traffic Safety Administration. General estimates system 1995. Washington, DC: US Department of estimates system 1995.

18 SAS Institute Inc. SAS for Windows, rel. 6.12. Cary, NC: SAS Institute Inc, 1997 .

19 SPSS Inc. SPSS for Windows, rel. 7.5.2. Chicago, IL: SPSS Inc, 1997 .

20 Langley JD, Wagenaar AC, Begg DJ. An evaluation of the New Zealand graduated driver licensing system. Accid Anal Prev 1996;28:139-46.

21 Mayhew DR, Simpson HM, Ferguson SA, et al. Graduated licensing in Nova Scotia: a survey of teenagers and parents. $\mathcal{F}$ Traffic Med 1998;26:37-44

22 Williams AF, Preusser DF. Night driving restrictions for youthful drivers: a literature review and commentary. $\mathcal{F}$ Public Health Policy 1997;18:334-45.

23 Laapotti S, Keskinen E, Hatakka M, et al. Young drivers and their passengers. Proceedings of the 24th International Congress of Applied Psychology. San Francisco, CA, 1998. 